\title{
Cerebrospinal fluid hypersecretion in pediatric hydrocephalus
}

\author{
*Jason K. Karimy, MS,' Daniel Duran, MD,1 Jamie K. Hu, BS, ${ }^{1}$ Charuta Gavankar, BA, ${ }^{1}$ \\ Jonathan R. Gaillard, BS, ${ }^{1}$ Yasar Bayri, MD, ${ }^{2}$ Hunter Rice, ${ }^{1}$ Michael L. DiLuna, MD, ${ }^{1}$ \\ Volodymyr Gerzanich, MD, PhD, ${ }^{3}$ J. Marc Simard, MD, PhD, ${ }^{3,4}$ and Kristopher T. Kahle, MD, PhD ${ }^{1,5}$
}

\begin{abstract}
Departments of ${ }^{1}$ Neurosurgery and ${ }^{5}$ Pediatrics, Cellular, and Molecular Physiology and Centers for Mendelian Genomics, Yale School of Medicine, New Haven, Connecticut; '2Department of Neurosurgery, Marmara University School of Medicine, Istanbul, Turkey; and Departments of ${ }^{3}$ Neurosurgery and ${ }^{4}$ Pathology and Physiology, University of Maryland School of Medicine, Baltimore, Maryland
\end{abstract}

Hydrocephalus, despite its heterogeneous causes, is ultimately a disease of disordered CSF homeostasis that results in pathological expansion of the cerebral ventricles. Our current understanding of the pathophysiology of hydrocephalus is inadequate but evolving. Over this past century, the majority of hydrocephalus cases has been explained by functional or anatomical obstructions to bulk CSF flow. More recently, hydrodynamic models of hydrocephalus have emphasized the role of abnormal intracranial pulsations in disease pathogenesis. Here, the authors review the molecular mechanisms of CSF secretion by the choroid plexus epithelium, the most efficient and actively secreting epithelium in the human body, and provide experimental and clinical evidence for the role of increased CSF production in hydrocephalus. Although the choroid plexus epithelium might have only an indirect influence on the pathogenesis of many types of pediatric hydrocephalus, the ability to modify CSF secretion with drugs newer than acetazolamide or furosemide would be an invaluable component of future therapies to alleviate permanent shunt dependence. Investigation into the human genetics of developmental hydrocephalus and choroid plexus hyperplasia, and the molecular physiology of the ion channels and transporters responsible for CSF secretion, might yield novel targets that could be exploited for pharmacotherapeutic intervention.

http://thejns.org/doi/abs/10.3171/2016.8.FOCUS16278

KEY WORDS pediatric hydrocephalus; choroid plexus; cerebrospinal fluid; ion transport; epithelia; NKCC1

$\mathrm{H}$ YDROCEPHALUS is a heterogeneous group of conditions, an overarching feature of which is disordered CSF homeostasis, which typically leads to an abnormal dilation of the cerebral ventricles (i.e., ventriculomegaly) that is often associated with increased intracranial pressure. ${ }^{71}$ In children, hydrocephalus is anatomically and mechanistically complex; as a consequence, there are multiple overlapping classification schemes that complicate its treatment by neurosurgeons and its investigation by scientists. ${ }^{128}$ Symptoms depend on the age of onset; infants usually present with progressive macrocephaly, whereas older children present with symptoms of intracranial hypertension. ${ }^{71}$ Hydrocephalus can disrupt brain development and lead to deficits in cognition and motor and sensory function. ${ }^{111}$ If untreated, hydrocephalus can cause brain herniation and death.

Hydrocephalus is a common cause of childhood morbidity and death and imposes a major financial burden on the US health care budget. ${ }^{12}$ The treatment of hydrocephalus is focused on relieving the symptoms it causes, which often includes the placement of ventriculoperitoneal shunts that are subject to frequent failure and surgical revision. ${ }^{12}$ Despite its prevalence and significance, the pathophysiology of hydrocephalus is poorly understood, and treatment options have not changed significantly in decades. ${ }^{87}$ Evidence indicates that genetic factors play a major role in the

ABBREVIATIONS $\mathrm{AE} 2=$ anion exchanger $2 ; \mathrm{AQP}=$ aquaporin $; \mathrm{BIF}=$ brain interstitial fluid $; \mathrm{CA}=$ carbonic anhydrase $; \mathrm{CPC}=$ choroid plexus cauterization; $\mathrm{CPE}=$ choroid plexus epithelium; $\mathrm{CPH}=$ choroid plexus hyperplasia; $\mathrm{CPP}=$ choroid plexus papilloma; $\mathrm{ETV}=$ endoscopic third ventriculostomy; $\mathrm{EVD}=$ external ventricular drain; $\mathrm{KCC}=$ $\mathrm{K}^{+}-\mathrm{Cl}-$ cotransporter; $\mathrm{NBCe} 2=\mathrm{Na}^{+}-\mathrm{HCO}_{3}{ }^{-}$cotransporter; $\mathrm{NCBE}=\mathrm{Na}^{+}-\mathrm{HCO}_{3}{ }^{-}$exchanger; $\mathrm{NKCC} 1=\mathrm{Na}^{+}-\mathrm{K}^{+}-2 \mathrm{Cl}^{-}$cotransporter; SPAK $=\mathrm{Ste} 20 / \mathrm{SPS} 1-$ related proline-alaninerich protein kinase.

SUBMITTED July 1, 2016. ACCEPTED August 15, 2016.

INCLUDE WHEN CITING DOI: 10.3171/2016.8.FOCUS16278.

${ }^{*}$ Mr. Karimy and Dr. Duran contributed equally to this work. 
pathogenesis of congenital hydrocephalus ${ }^{78}$ and although results of animal studies have contributed to our understanding of the disease, ${ }^{87}$ our knowledge of the genetic determinants and molecular mechanisms of most types of pediatric hydrocephalus, especially developmental (i.e., congenital) hydrocephalus, is primitive.

For the past century, the standard bulk flow model of CSF physiology was the paradigm used most commonly to explain the pathogenesis of hydrocephalus. ${ }^{30}$ In this model, CSF is secreted by the choroid plexus in the cerebral ventricles, flows from the lateral ventricles to the third and fourth ventricles, exits the fourth ventricle via the foramina of Luschka and Magendie into the subarachnoid space, circulates around the cerebral convexity and spinal cord, and is absorbed into the cerebral venous system by the arachnoid granulations. According to this scheme, hydrocephalus results from obstruction to CSF flow anywhere along this pathway. More recently, in an alternative hydrodynamic model of hydrocephalus, the role of abnormal intracranial pulsations in disease pathogenesis is emphasize $\mathrm{d}^{10,37,50,131}$ and better accounts for observations that are inconsistent with the bulk flow model, including the following: 1) functional arachnoid granulations are not present in children younger than 2 years; $; .98$ 2) the ependyma and sites other than the choroid plexus might account for a significant amount of CSF production;89 3) increasing intraventricular CSF osmolality is sufficient to cause experimental hydrocephalus; ${ }^{79}$ and 4 ) despite unobstructed flow and normal mean CSF pressures, increasing intraventricular fluid pulsation amplitudes alone are sufficient to cause hydrocephalus. ${ }^{36,131,132}$

Most types of pediatric hydrocephalus are characterized ultimately by an abnormal accumulation of CSF. Despite this fact, it is surprising that the role of CSF secretion in the pathogenesis of hydrocephalus has been neglected. Nonetheless, pharmacological (e.g., acetazolamide) and surgical (e.g., choroid plexus cauterization [CPC]) strategies that decrease CSF production have been shown to be successful for specific hydrocephalus subtypes. ${ }^{17,109}$ Here, we review the physiological and molecular mechanisms of CSF secretion by the choroid plexus and provide evidence for the role of increased CSF production in animal models and children with hydrocephalus. We propose that CSF hypersecretion is probably an underrecognized mechanism of hydrocephalus in at least certain pediatric hydrocephalus subtypes. We suggest that improved knowledge of the molecular physiology of choroid plexus ion-transport pathways and the regulatory mechanisms that control the rate of CSF secretion might uncover targets that could be exploited in novel pharmacotherapeutic strategies for treating hydrocephalus.

\section{Mechanisms of CSF Secretion}

The choroid plexus is a highly vascularized network of fenestrated capillaries surrounded by polarized cuboidal epithelial cells connected via tight junctions. ${ }^{28,34,114,122}$ Unlike the blood-brain barrier, which is formed by tight junctions of cerebral endothelia, the blood-CSF barrier is formed by the tight junctions between choroid plexus epithelial cells (Fig. 1) ${ }^{28,29}$ The fenestrated capillaries of the choroid plexus are leaky and, in contrast to cerebral endothelia, readily allow the passage of ions and other small molecules. 5,121,124,146

The choroid plexus was first suggested as a site of CSF secretion by Faivre in $1854^{41}$ and by Cushing in $1914,{ }^{25}$ and in 1960, De Rougemont et al. ${ }^{33}$ provided the first direct experimental evidence of choroid plexus-dependent CSF secretion. Although the theory is controversial, according to most models, the choroid plexus epithelium (CPE) generates a significant fraction, if not the majority, of CSF. Most recent estimates have indicated that the CPE generates approximately $80 \%$ of CSF, whereas the remaining $20 \%$ is derived from brain interstitial fluid (BIF). ${ }^{13}$ The $\mathrm{CPE}$ is among the most efficient secretory epithelia in the human body; it produces CSF at a rate of $0.4 \mathrm{~mL} /$ minute per gram of tissue, a secretion rate that is rivaled only by the proximal tubule of the kidney and the ducts of the exocrine pancreas. ${ }^{28}$

The total volume of CSF in the entire human CNS (i.e., within the cerebral ventricles and the subarachnoid spaces) is approximately $150 \mathrm{ml}$; however, it is estimated that $500-600 \mathrm{ml}$ are produced every 24 hours. Thus, CSF volume is replaced 3-4 times per day, and if pathways to CSF reabsorption are blocked or compromised, CSF will accumulate rapidly and the ventricles will expand, which raises an obvious question: where and how is CSF reabsorbed? Classical teaching is that the arachnoid granulations perform this function; however, many of the animal models in which hydrocephalus is studied ${ }^{98,126}$ and young children ${ }^{7}$ do not seem to have functional arachnoid granulations. This realization highlights the presence of additional players that influence the delicate balance of CSF homeostasis. As mentioned already, BIF contributes to approximately one-fifth of total CSF production..$^{13}$ It was recognized recently that the flow of BIF is dynamic; it follows a preferentially perivascular route and traverses the complex microanatomy of the Virchow-Robin space.,13 Evidence shows that the flow of BIF is not unidirectional and can contribute to both net CSF production and reabsorption. Hence, there is constant exchange between BIF and CSF. ${ }^{66}$ The constituents of this dynamic mechanism have been called the "glymphatic system."

The literature presents this system most often as a paravascular route that facilitates the movement of subarachnoid CSF into BIF and then out through the deep draining veins. ${ }^{61,62}$ These paravascular channels are bound by astrocytic end feet containing aquaporin $4(\mathrm{AQP} 4)^{60}$ that, when dysfunctional, can contribute to or exacerbate the development of hydrocephalus. ${ }^{60}$ In other words, it is depicted predominantly in the mammalian CNS as a route of CSF reabsorption. However, the influence of this system as a route for transependymal, extracellular movement of water into CSF spaces, contributing to net CSF production, must not be ignored and should be interpreted as an additional factor that influences therapeutic interventions aimed at controlling alterations in CSF homeostasis. Moreover, the role of the glymphatic system in adaptation of CSF secretion when other parts of the system (i.e., the choroid plexus) have been manipulated, either surgically or medically, is still unknown.

The choroid plexus has the highest rate of ion and wa- 


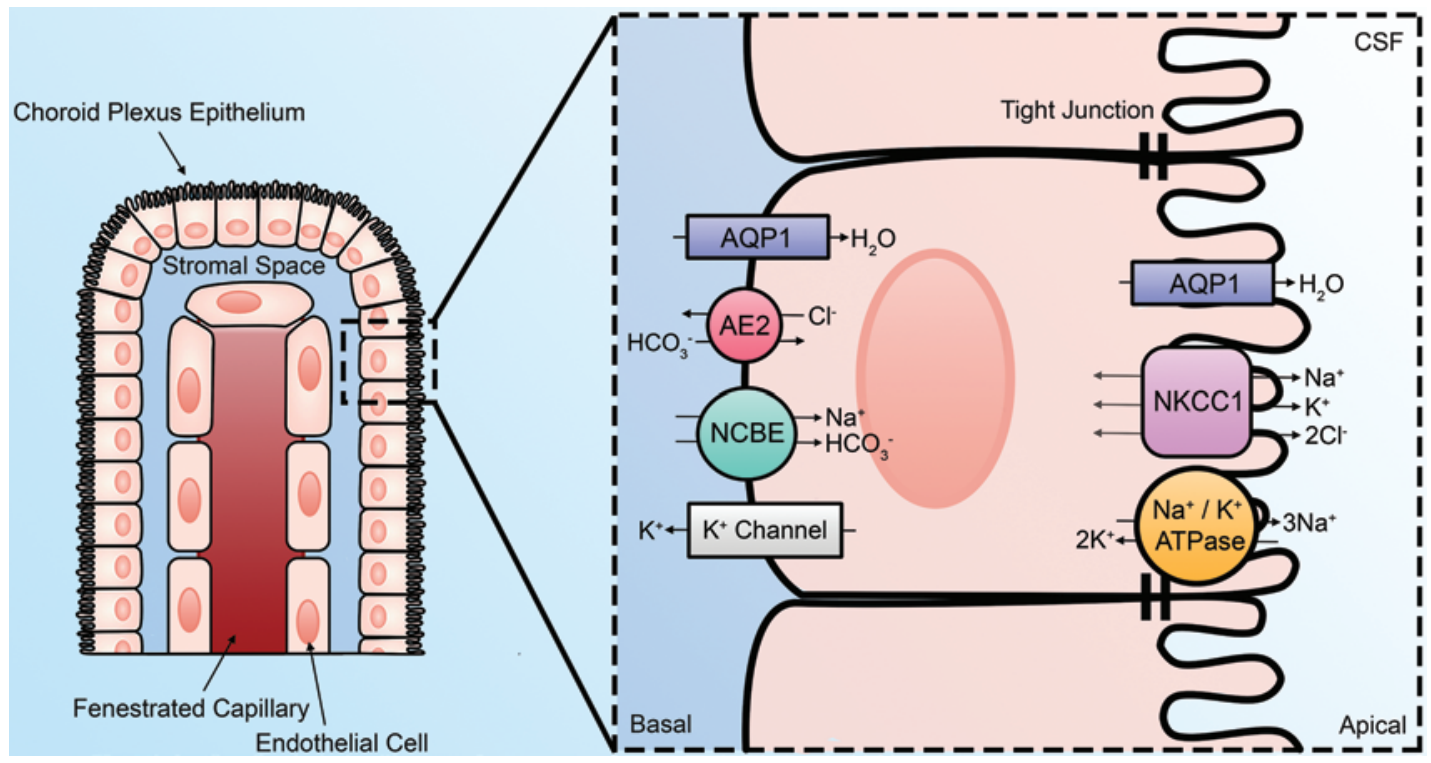

FIG. 1. Model for CSF secretion by the CPE; $A E 2$ and $\mathrm{NCBE}$, at an $\mathrm{Na} / \mathrm{Cl} / \mathrm{HCO}_{3}{ }^{-}$ratio of $18: 15: 3$, transports ions taken up from the basolateral membrane (blood) side into choroid plexus epithelial cells. A large fraction of the $\mathrm{Cl}^{-}$and $\mathrm{HCO}_{3}{ }^{-}$influx is recycled across the basolateral membrane. At the luminal (ventricular) side, the $\mathrm{Na}^{+} / \mathrm{K}^{+}-\mathrm{ATPase}$ extrudes most of the $\mathrm{Na}^{+}$. A small contribution to luminal $\mathrm{Na}^{+}$extrusion is made by $\mathrm{NBCe} 2$, which cotransports $\mathrm{HCO}_{3}{ }^{-}$. The $\mathrm{K}-\mathrm{Cl}-$ cotransporter, $\mathrm{KCC}$, a genetic relative of the bumetanide-sensitive $\mathrm{Na}^{+}-\mathrm{K}^{+}-2 \mathrm{Cl}^{-}$cotransporter, NKCC1 (see below), which is inhibited by furosemide, secretes the majority of $\mathrm{Cl}^{-}$into the CSF lumen. KCC4 is also a main pathway of luminal $\mathrm{K}^{+}$recycling, which is required for sustained CSF secretion. A fraction of the $\mathrm{Na}^{+}$extruded into the CSF must reenter the cell via NKCC1 to keep the stoichiometry of the secreted ions to an approximate $\mathrm{Na} / \mathrm{Cl} / \mathrm{HCO}_{3}-$ ratio of $18: 15: 3$. This Na-recycling mechanism is accompanied by extrusion of the imported $\mathrm{K}^{+}$and $\mathrm{Cl}^{-}$via their respective apically expressed ion channels. Because its driving force is close to equilibrium, NKCC1 can mediate the bidirectional transport of ions depending on ion gradients between the blood and CSF. In addition, NKCC1 is highly regulated by SPAK, which in turn is sensitive to changes in intracellular $\mathrm{Cl}^{-}$levels and other stimuli, such as osmotic stress and inflammation. It should be noted that ion gradients generated by the primary active $\mathrm{Na}^{+} / \mathrm{K}^{+}-\mathrm{ATPase}$, which directly pumps out net solute to the CSF, also powers the transcellular movement of ions via the aforementioned $\mathrm{Na}^{+}$- and $\mathrm{K}^{+}$-coupled cotransporters and exchangers. Net ion movement from the blood side to the CSF side creates a small osmolarity difference between these 2 compartments. Water is subsequently "dragged" via osmotic forces across the epithelium and traverses the apical membrane of the choroid plexus epithelial cell through AQP1 in both the luminal and basolateral membranes.

ter transport of any epithelium in humans. ${ }^{28,82}$ Secretion of CSF is achieved through the net transport of solutes $\left(\mathrm{Na}^{+}\right.$, $\mathrm{Cl}^{-}$, and $\mathrm{HCO}_{3}^{-}$, along with the recycling of $\mathrm{K}^{+}$) across the CPE into the ventricles across the apical and basolateral membranes of the CPE. ${ }^{114}$ Net transcellular solute influx results in a transepithelial osmotic gradient that favors osmotically driven transcellular movement of water across the CPE. $\mathrm{Na}^{+}$and $\mathrm{Cl}^{-}$are quantitatively the most important ions involved in CSF secretion, and the overall process of CSF secretion is known to depend highly on $\mathrm{HCO}_{3}{ }^{-}$. It is currently unclear what role the paracellular route of ion movement, primarily that of $\mathrm{Na}^{+}$, has in CSF secretion. ${ }^{29,114,124}$ Unlike in most secretory epithelia, tight junctions between choroid plexus epithelial cells resist the movement of $\mathrm{Na}^{+}$and water, which suggests that CSF secretion is primarily a transcellular process. ${ }^{124}$ It is interesting to note that the final solute concentrations within the CSF are regulated carefully, and they remain relatively stable even when plasma concentrations vary and demonstrate tight regulation of ion transport. ${ }^{28,29,114,124}$ The individual channels and transporters involved in ion and water transport required for CSF secretion have not been cataloged completely, but several are of known importance. ${ }^{28}$ On the basolateral membrane, anion exchanger 2 (AE2) and $\mathrm{Na}^{+}-\mathrm{HCO}_{3}{ }^{-}$exchanger $\mathrm{NCBE}$ drive the movement of $\mathrm{Na}^{+}, \mathrm{Cl}^{-}$, and $\mathrm{HCO}_{3}{ }^{-}$from the blood into the CPE. On the luminal membrane, $\mathrm{Na}^{+} / \mathrm{K}^{+}$-ATPase, $\mathrm{Na}^{+}-\mathrm{K}^{+}-2 \mathrm{Cl}^{-}$cotransporter $(\mathrm{NKCC} 1), \mathrm{Na}^{+}-\mathrm{HCO}_{3}{ }^{-}$cotransporter $(\mathrm{NBCe} 2)$, the $\mathrm{K}^{+}-\mathrm{Cl}^{-}$and cotransporter 4 (KCC4, a relative of NKCC1), and $\mathrm{K}^{+}$and $\mathrm{Cl}^{-}$channels coordinate the transport of $\mathrm{Na}^{+}$, $\mathrm{K}^{+}, \mathrm{Cl}^{-}$, and $\mathrm{HCO}_{3}{ }^{-}$into the $\mathrm{CSF}$ and recycle ions back into the CPE.

The luminal membrane of choroid plexus epithelial cells has high water permeability, ${ }^{99}$ and passive transcellular movement of water from blood to the ventricles is mediated largely through AQP $1 .^{95}$ Permeability of the CPE is reduced by $80 \%$ in cells from AQP1 knockout mice. ${ }^{99}$ It should be emphasized, however, that high AQP1 expression itself does not confer an increase in the secretory capacity of the CPE, because water movement requires a driving force (as mentioned earlier), and basolateral water entry (the mediators of which are not well defined) can be rate limiting. Aquaporins other than AQP1 might be expressed in the choroid plexus basolateral membrane.

The transport of $\mathrm{Na}^{+}$across the luminal membrane of the CPE is achieved largely by $\mathrm{Na}^{+} / \mathrm{K}^{+}$-ATPase. ${ }^{2,44}$ Several studies that inhibited $\mathrm{Na}^{+} / \mathrm{K}^{+}$-ATPase with ouabain on the luminal side of the CPE found a decrease in CSF produc- 
tion. ${ }^{49,57}$ These results suggest that $\mathrm{Na}^{+}$flux is a primary driver of CSF secretion and that the $\mathrm{Na}^{+} / \mathrm{K}^{+}$-ATPase is integral for maintaining the osmotic and electrochemical gradient required for CSF secretion. ${ }^{49,57}$ Carbonic anhydrases (CAs) are a large family of enzymes that convert $\mathrm{H}_{2} \mathrm{O}$ and $\mathrm{CO}_{2}$ into $\mathrm{H}^{+}$and $\mathrm{HCO}_{3}{ }^{-}$, which provides the $\mathrm{HCO}_{3}{ }^{-}$needed for $\mathrm{Na}^{+} / \mathrm{HCO}_{3}{ }^{-}$cotransport, a key step in maintaining electroneutrality across the blood-CSF barrier. Studies have found the presence of CAII and CAIII in human and murine CPE. ${ }^{69,123}$ Partial reduction of CSF secretion by pharmacological inhibition of CA by acetazolamide highlights the importance of this enzyme in CSF homeostasis. . $^{17,130}$

$\mathrm{NKCCl}$ is highly expressed in the luminal (apical) membrane of the CPE. ${ }^{13}$ In most secretory epithelia, NKCC1, the $\mathrm{Na}^{+} / \mathrm{K}^{+}$-ATPase, and $\mathrm{K}^{+}$channels are located on the basolateral membrane, and $\mathrm{Cl}^{-}$channels are located on the apical membrane. ${ }^{28,29,114,124}$ The CPE is unique and exhibits the opposite polarity in the expression of these transporters, which creates a slight net positive electrochemical gradient and makes $\mathrm{Na}^{+}$movement an active energy-dependent process that occurs primarily through transcellular mechanisms. ${ }^{28,29,114,124}$ The stoichiometric coupling and directionality of the cations and $\mathrm{Cl}^{-}$ions translocated by $\mathrm{NKCCl}$ results in an electrically silent (i.e., electroneutral) secondarily active transport process that is energetically driven by transmembrane $\mathrm{Na}^{+}$and $\mathrm{K}^{+}$gradients established by $\mathrm{Na}^{+} / \mathrm{K}^{+}$-ATPase. $\mathrm{NKCCl}$ is inhibited by bumetanide and, to a much lesser extent, by furosemide. ${ }^{116}$ Similar to NKCC1, the KCCs are inhibited by furosemide; however, bumetanide inhibits the KCC cotransporters 1000 times less potently than NKCC1. ${ }^{116}$ The driving force for $\mathrm{NKCC} 1$ in choroid plexus epithelial cells is close to equilibrium, given the relatively low $\mathrm{K}^{+}$concentration of CSF and high intracellular concentration of $\mathrm{Na}^{+}$. Consistent with this fact, there is evidence that NKCC1 mediates both outward-directed (into the CSF lumen) and inward-directed ion transport. ${ }^{75,107,147}$ Because the ion composition of CSF is tightly regulated and maintained, ${ }^{58,94,114}$ the bidirectional ion movement via NKCC1 might enable it to respond dynamically to physiological changes in the CSF to maintain homeostasis. In other secretory epithelia, the Ste20/SPS1-related proline-alanine-rich protein kinase (SPAK) associates with NKCC1 via a CCT-binding module in SPAK and a $(\mathrm{R} / \mathrm{K}) \mathrm{FX}(\mathrm{V} / \mathrm{I})$-binding motif in $\mathrm{NKCC1}^{105}$ and stimulates NKCC1 via direct phosphorylation at Thr203/Thr-207/Thr-212.9,72 The importance of SPAK in the dynamic regulation of $\mathrm{NKCC} 1$ in renal, ${ }^{47,48}$ intestinal, ${ }^{47,148}$ and pancreatic ${ }^{47,101}$ epithelia is well documented. However, a potential role in the CPE for SPAK-NKCC1-mediated regulation has not been well studied.

The upstream mechanisms that regulate the rate of production and the composition of CSF are less well known. ${ }^{23,28,110}$ However, many of the important hormones and their receptors that regulate systemic $\mathrm{NaCl}$ and water homeostasis, including aldosterone, angiotensin II, and vasopressin, are expressed in the CPE and ependyma also and likely play local roles in the CPE with respect to CSF production and brain extracellular fluid-volume regulation.

\section{Hydrocephalus and CSF Production}

The rates of CSF production and reabsorption must be in equilibrium. Disturbances in homeostasis can lead to hydrocephalus that results from CSF hypersecretion secondary to choroid plexus hyperplasia $(\mathrm{CPH})^{4}$ or nonobstructive tumors of the choroid plexus, such as choroid plexus papilloma (CPP) ${ }^{11}$ which are rare causes of pediatric hydrocephalus. In the literature, $\mathrm{CPH}$ is also referred to as diffuse villous hyperplasia of the choroid plexus or villous hypertrophy. ${ }^{4}$ The difference between hyperplasia and hypertrophy of the choroid plexus is not always stated explicitly; therefore, for the purposes of this review, cases of $\mathrm{CPH}$, diffuse villous hyperplasia of the choroid plexus, and villous hypertrophy will be referred to as cases of $\mathrm{CPH}$.

Choroid plexus papilloma is a rare intracranial tumor that accounts for $1 \%-4 \%$ of all pediatric brain tumors. ${ }^{35,52}$ It is a distinct mass that is separate from the CPE and often presents within the first 2 years of life. Choroid plexus hyperplasia is a rare congenital disorder that causes the $\mathrm{CPE}$ to become enlarged and hypersecrete CSF, typically by an increase in the number of normal choroid plexus epithelial cells. The diagnosis of hydrocephalus with CPP and $\mathrm{CPH}$ origin is critical, because the standard treatment is not a shunt procedure but, rather, resection of the tumor or excessive CPE. ${ }^{4,27,45}$ The initial diagnosis of CPP or CPH has been difficult historically, especially before imaging techniques such as MRI. ${ }^{27,55}$ In general, the diagnosis is made after shunt failure or the development of ascites, which prompts a revision or externalization of the shunt. If the shunt is externalized, the external ventricular drain (EVD) illuminates the excessive rate of CSF production, which leads to a diagnosis.

To date, 27 cases of CPP $21,35,38-40,46,51,52,90,96,102,103,113,149$ and $\mathrm{CPH}^{3,4,14,20,27,45,55,56,64,104,123,142,143}$ have been reported to be associated with nonobstructive hydrocephalus; the rates of CSF hypersecretion were reported for 19 of those cases (Table 1). Normal production of CSF is approximately 500 $\mathrm{ml} /$ day $^{26}$; however, in the setting of CPP or CPH, CSF secretion rates were reported to be up to $5000 \mathrm{ml} /$ day, and higher rates correlated with more severe hydrocephalus (Table 1). $3,4,14,18,20,27,38,40,46,55,56,90,96,102,117,123,127$ After surgical intervention (e.g., CPC or tumor removal), the rates of CSF production decreased, ${ }^{4,20,35,46,51,90,96,117}$ and in some cases, there was no further need for a shunt. ${ }^{27,51,56}$ In addition to $\mathrm{CPP}$ and $\mathrm{CPH}$, overproduction of CSF contributing to hydrocephalus has also been implicated in idiopathic intracranial hypertension, ${ }^{59}$ infectious hydrocephalus, ${ }^{16}$ and intraventricular hemorrhage-associated hydrocephalus, ${ }^{126}$ but secretion rates in the patients with these conditions have not been well documented.

From a molecular physiology perspective, many solute(ion channel and transporters) and water-transport (AQP) pathways of the choroid plexus have been implicated in the pathogenesis of hydrocephalus in humans and in animal models. ${ }^{24,43,53,63,67,100,108,112,120,129,145}$ For example, AQP4 is expressed in glia and ependymocytes, and a subset of AQP4 knockout mice develop severe obstructive hydrocephalus as a result of total obstruction of the cerebral aqueduct. ${ }^{42}$ In contrast, ependymal AQP4 is upregulated in the late stages of hydrocephalus, possibly as a compen- 
TABLE 1. Case reports of hydrocephalus associated with CSF hypersecretion

\begin{tabular}{|c|c|c|c|c|}
\hline Pathology & Age \& Sex & CSF Secretion (ml/24 hrs) & Method of Measurement & Authors \& Year \\
\hline \multirow[t]{10}{*}{ CPP } & 10 days, $\mathrm{F}$ & $800-1000$ & EVD & Di Rocco \& lannelli, 1997 \\
\hline & $5 \mathrm{mos}, \mathrm{F}$ & $2000^{*}$ & VLP & Eisenberg et al., 1974 \\
\hline & $15 \mathrm{mos}, \mathrm{F}$ & $400-960$ & EVD & Fairburn, 1960 \\
\hline & 10 mos, M & 2000 & EVD & Fujimura et al., 2004 \\
\hline & 3.5 yrs, $F$ & $2280^{*}$ & EVD & Gudeman et al., 1979 \\
\hline & 23 mos, M & $1500^{*}$ & VLP & Milhorat et al., 1976 \\
\hline & $6 \mathrm{mos}, \mathrm{F}$ & $3200-5000$ & EVD & Nimjee et al., 2010 \\
\hline & $8 \mathrm{mos}, \mathrm{F}$ & $1400-1500$ & EVD & Pawar et al., 2003 \\
\hline & 2 yrs, M & $900-1200$ & EVD & Pawar et al., 2003 \\
\hline & 22 mos, F & $800-1500$ & EVD & Saito et al., 2014 \\
\hline \multirow[t]{9}{*}{$\mathrm{CPH}$} & $8 \mathrm{mos}, \mathrm{F}$ & 1500 & EVD & Anei et al., 2011 \\
\hline & $11 \mathrm{yrs}, \mathrm{M}$ & $4200^{*}$ & EVD & Aziz et al., 2005 \\
\hline & $3 \mathrm{mos}, \mathrm{M}$ & 900 & EVD & Britz et al., 1996 \\
\hline & 9 days, $M$ & 2000 & EVD & Cataltepe et al., 2010 \\
\hline & $7 \mathrm{mos}, \mathrm{F}$ & 1200 & EVD & D’Ambrosio et al., 2003 \\
\hline & 3 yrs, F & 2000 & EVD & Hallaert et al., 2012 \\
\hline & $7 \mathrm{yrs}, \mathrm{F}$ & 2000 & EVD & Hirano et al., 1994 \\
\hline & 15 mos, F & 1400 & EVD & Smith et al., 2007 \\
\hline & $24 \mathrm{mos}, \mathrm{F}$ & 2000 & EVD & Tamburrini et al., 2006 \\
\hline Unknown & $2.5 \mathrm{yrs}, \mathrm{NA}$ & $2000^{*}$ & EVD & Casey \& Vries, 1989 \\
\hline
\end{tabular}

satory mechanism to maintain water homeostasis..$^{19,86}$ In addition, it has been well documented that the ependymal cells lining the ventricular space have motile cilia and that defects in motile cilia lead to hydrocephalus. ${ }^{6,84}$ Mice with mutations in the cilia proteins Spag6 or hydin, or the transcription factor Hfh4 (Foxj1, Mouse Genome Informatics) that lack ependymal cell cilia all exhibit hydrocephalus. ${ }^{22,32,118}$ Cilia function in the CSF ventricular system is also important in humans, as evidenced by the incidence of hydrocephalus in human patients with primary ciliary dyskinesias. ${ }^{15}$ Data from hydrocephalic murine $E 2 F-5$ and Tg737 ${ }^{\text {rp }}$ mutants support a model in which cilia dysfunction leads not only to disrupted ependymal cilia-generated CSF flow but also elevated intracellular cyclic adenosine monophosphate (cAMP) levels, an increased $\mathrm{Cl}^{-}$concentration in the CSF, and a marked increase in CSF production. ${ }^{6,84}$ Altogether, these data suggest that cilia function is necessary for regulating ion transport and CSF production, as well as CSF flow through the ventricular system.

\section{Medical Management of Hydrocephalus by Targeting CSF Production}

Knowledge of the molecular mechanisms of CSF secretion, although incomplete, has improved over the past few decades. As a direct result of this knowledge, pharmacological disruption of these mechanisms as a means of modulating CSF secretion has become commonplace. Diuretics are, by far, the drugs used most commonly for this purpose. However, these drugs are often ineffective, have adverse effects, and have off-target effects in the kidney.
Acetazolamide, a CA inhibitor, has been shown to lead to an approximately 30\%-60\% decrease in CSF rate and daily output. ${ }^{17,74,88,93}$ As reviewed earlier, the charge gradient created by transport of positive ions (primarily $\mathrm{Na}^{+}$) into the ventricular space is balanced by the cotransport of bicarbonate, which is produced by $\mathrm{CA}$ in the intracellular compartment. However, the precise mechanism by which acetazolamide reduces CSF production is not completely understood. The partial effect of this inhibitor might be explained by the presence of acetazolamide-insensitive CAIII, which has been found in humans and in animal models. ${ }^{97}$

Loop diuretics have also been used in an attempt to mitigate the effects of CSF hypersecretion. Bumetanide (an NKCC1 inhibitor) and furosemide (a KCC inhibitor), alone or in combination with acetazolamide, have been documented to decrease CSF production in canine and feline models. ${ }^{65,70}$ The effect of bumetanide on CSF production, in conjunction with its selectivity for $\mathrm{NKCC} 1$, highlights the importance of this transporter in CSF homeostasis. Animal evidence also reveals the effect of furosemide in disrupting ion transport across the bloodCSF barrier, which reduces the rate of CSF secretion. ${ }^{68,85}$ Because the effects of these drugs were also observed in animals that underwent a nephrectomy, potential secondary diuretic or hemodynamic effects caused by renal electrolyte imbalance, including the development of acid-base disturbances, are unlikely to explain the decrease in CSF production. ${ }^{88,115}$

Despite theoretical effectiveness and encouraging results from animal models, a randomized controlled trial in 
which parenteral administration of a combination of acetazolamide and furosemide was used in patients with posthemorrhagic hydrocephalus $(\mathrm{n}=177)$ found that the drugs led to a higher rate of shunt placement and an increase in neurological morbidity (auditory) in the cohort. ${ }^{63,76} \mathrm{~A}$ smaller trial ( $n=16$ patients) performed shortly thereafter that involved administering intravenous acetazolamide plus furosemide versus serial lumbar puncture in preterm infants with posthemorrhagic hydrocephalus found that 9 of 10 infants who received the drug combination avoided shunt placement, whereas only 3 of 6 assigned to serial LPs experienced the same result. However, the authors reported that a significant proportion of the infants developed nephrocalcinosis as a result of pharmacotherapy ${ }^{83} \mathrm{~A}$ systematic Cochrane review, which included both of these trials, reinforced the conclusion that combination therapy with acetazolamide and furosemide is neither effective nor safe in treating posthemorrhagic hydrocephalus. ${ }^{145}$

In summary, the use of diuretics for pediatric hydrocephalus is severely limited by its low effectiveness in adequately suppressing CSF production when administered enterally or parenterally, which might be because of the poor transcellular passage of these drugs in the CPE and, in the case of furosemide and bumetanide, their inability to reach their target transporters on the apical membrane of the CPE. This limitation is complicated further by a significant adverse-effect profile secondary to their influence on other transport epithelia, primarily in the kidney. In light of these circumstances, it would be very interesting to test the utility of bumetanide administered via an intracerebroventricular approach, such as through an EVD or Ommaya reservoir, on CSF secretion and hydrocephalus in humans. These observations also underscore the need for newer and more specific and potent drugs.

\section{Modulation of CSF Secretion by Surgical Intervention of the Choroid Plexus}

Operative techniques that involve targeting CSF production have been described in the literature for close to 100 years. Dandy ${ }^{31}$ described one of the earliest surgical interventions for treating hydrocephalus by means of ablating the choroid plexus. Early results from small series of choroid plexus cauterization alone for hydrocephalus were modest. ${ }^{109,119} \mathrm{~A}$ few attempts have been made over the past 3 decades to describe the effect of choroid plexus disruption through either plexectomy or cauterization. A small series of 17 patients with "chronic hydrocephalus" underwent primary choroid plexectomy; the authors reported a $37 \%$ success rate, defined as avoidance of CSF-diversion procedures. ${ }^{81}$ Subsequent small series in selected patients who underwent either CPC or plexectomy found advantages in terms of reduced rates of reoperation, readmission, or operative complications. ${ }^{92,144}$ The underlying motif for these reports points to adequate patient selection as a key determinant in maximizing the chances of shunt avoidance when performing isolated choroid plexus-disruption procedures.

A single large series, the report for which was published in 1994, included a cohort of 90 children who underwent primary $\mathrm{CPC}$ as the single initial intervention for hydrocephalus of multiple etiologies. The group reported that
$36 \%$ of the patients did not require shunt placement in the mean follow-up period of 10.5 years. It is interesting to note that success rates were higher in patients with communicating hydrocephalus and in those with slow progression of ventriculomegaly, ${ }^{109}$ which further reinforces the concept that careful patient selection is a key determinant in selecting an adequate surgical approach. This notion probably parallels the pathophysiological diversity of hydrocephalus, which emphasizes the need for better and more precise interventions that deal with the underlying mechanism of disease.

The modern experience with CPC has been in combination with endoscopic third ventriculostomy (ETV), reported initially by Warf ${ }^{134}$ after extensive experience in Uganda. The ETV-CPC procedure involves using a flexible endoscope and monopolar cautery to coagulate the entire choroid plexus throughout both lateral ventricles. In accordance with the bulk flow model, ETV might bypass obstruction, and CPC might decrease CSF production; according to the hydrodynamic model, ETV might serve as a pulsation absorber, whereas CPC reduces the intraventricular pulsation amplitude. ${ }^{135,138}$

Compared with ETV alone, ETV-CPC yields superior results in children $<1$ year of age ${ }^{134}$ and in all studied etiological subgroups. ${ }^{136,137,139,141}$ The efficacy of ETV-CPC is proportional to the amount of choroid plexus cauterized ${ }^{140}$ and does not negatively affect cognition compared with shunting or ETV alone. ${ }^{133}$ However, other potential collateral effects of this treatment still remain unknown, including those related to immunological function and neurodevelopment. Based on these promising results in Uganda, ETV-CPC has been introduced in North America and produced favorable results in a single-institution series ${ }^{125}$ and in a preliminary study through the Hydrocephalus Clinical Research Network. ${ }^{80}$ In addition to ETV-CPC, preoperative embolization of choroid plexus tumors in children has been shown to decrease CSF production significantly by removing the blood supply of the tumor. ${ }^{54}$

It is unfortunate that few studies have been conducted to explore the true effect of choroid plexus ablation on CSF production, which clearly relates to the infeasibility of the invasive procedures used to estimate rates of CSF production (e.g., EVD) as a part of long-term patient follow-up. Hence, clinicians are limited by indirect indicators of diminished CSF production after surgical management, such as clinical improvement and/or resolution of ventriculomegaly observed via MRI. More recently, imaging techniques that allow the quantification of remaining choroid plexus or depict the presence of CSF turbulence after ETV-CPC have enhanced clinicians' ability to follow the effectiveness of these interventions. ${ }^{106}$

The best starting point for answering the true effect of choroid plexus ablation on CSF production comes from observations made by Milhorat et al. in the early 1970s. ${ }^{91}$ These meticulous studies revealed that choroid plexectomy reduced normal CSF production rates in Rhesus monkeys by an average of only $33 \%-40 \%$. This result, together with treatment failure in a nonnegligible proportion of patients treated with ETV-CPC (up to $45 \%$ of whom required shunt placement within the follow-up period), ${ }^{125,134}$ highlights the complexity of the pathophysiology of CSF homeostasis. As mentioned earlier, physiological adaptation to a change 
in the normal production of CSF might imply compensation by the remaining choroid plexus tissue not cauterized in standard endoscopic approaches or by upregulation of secondary mechanisms of secretion, as already mentioned earlier.

\section{Novel Strategies for Targeting CSF Production for the Treatment of Pediatric Hydrocephalus}

Despite the high prevalence of hydrocephalus, the molecular mechanism(s) leading to its pathology remains elusive in most cases. Thus, to develop alternative treatment strategies, a better understanding of the pathogenesis of this disease is needed. A 2015 National Institutes of Health-sponsored symposium listed the elucidation of the mechanisms underlying CSF production and the discovery of related drug therapies as top priorities for hydrocephalus research ${ }^{87}$ Critical in the effort to develop novel drugs to inhibit CSF secretion is defining the critical regulatory pathways that mediate this process. In any complex physiological process with multiple overlapping regulatory pathways, molecular genetics (both mouse and human) has the power to pinpoint key homeostatic nodes in an unbiased way. Next-generation DNA sequencing of humans with developmental hydrocephalus and of those with CPP or $\mathrm{CPH}$ with hydrocephalus, coupled with modeling these disease-causing mutations in mice with CRISPR/CAS gene editing, might help uncover novel mediators and regulators of CSF homeostasis. In addition to $\mathrm{CPP}$ and $\mathrm{CPH}, \mathrm{CSF}$ secretion and ion-transport mechanisms should be studied in other types of hydrocephalus, especially those associated with inflammation, such as infectious hydrocephalus ${ }^{16}$ and intraventricular hemorrhage-associated hydrocephalus. ${ }^{126}$ Another important line of investigation is for how to improve the drugs that are directed at known targets of CSF secretion, including NKCC1, AQP1, NCBE, AE2, and the V1a vasopressin receptors. In this regard, drugs capable of rapidly and reversibly inhibiting CSF secretion would be useful for not only acute hydrocephalus but also other neurosurgical conditions associated with high intracranial pressure, including cerebral edema. ${ }^{73,77}$

\section{Acknowledgments}

Dr. Kahle is supported by the March of Dimes, the Simons Foundation, and the National Institutes of Health Centers for Mendelian Genomics.

\section{References}

1. Abbott NJ: Evidence for bulk flow of brain interstitial fluid: significance for physiology and pathology. Neurochem Int 45:545-552, 2004

2. Amin MS, Reza E, Wang H, Leenen FH: Sodium transport in the choroid plexus and salt-sensitive hypertension. Hypertension 54:860-867, 2009

3. Anei R, Hayashi Y, Hiroshima S, Mitsui N, Orimoto R, Uemori G, et al: Hydrocephalus due to diffuse villous hyperplasia of the choroid plexus. Neurol Med Chir (Tokyo) 51:437-441, 2011

4. Aziz AA, Coleman L, Morokoff A, Maixner W: Diffuse choroid plexus hyperplasia: an under-diagnosed cause of hydrocephalus in children? Pediatr Radiol 35:815-818, 2005

5. Ballermann BJ, Stan RV: Resolved: capillary endothelium is a major contributor to the glomerular filtration barrier. J Am Soc Nephrol 18:2432-2438, 2007

6. Banizs B, Pike MM, Millican CL, Ferguson WB, Komlosi $\mathrm{P}$, Sheetz J, et al: Dysfunctional cilia lead to altered ependyma and choroid plexus function, and result in the formation of hydrocephalus. Development 132:5329-5339, 2005

7. Bateman GA, Alber M, Schuhmann MU: An association between external hydrocephalus in infants and reversible collapse of the venous sinuses. Neuropediatrics 45: 183187,2014

8. Bateman GA, Brown KM: The measurement of CSF flow through the aqueduct in normal and hydrocephalic children: from where does it come, to where does it go? Childs Nerv Syst 28:55-63, 2012

9. Begum G, Yuan H, Kahle KT, Li L, Wang S, Shi Y, et al: Inhibition of wnk3 kinase signaling reduces brain damage and accelerates neurological recovery after stroke. Stroke 46:1956-1965, 2015

10. Bering EA Jr: Circulation of the cerebrospinal fluid. Demonstration of the choroid plexuses as the generator of the force for flow of fluid and ventricular enlargement. J Neurosurg 19:405-413, 1962

11. Bettegowda C, Adogwa O, Mehta V, Chaichana KL, Weingart J, Carson BS, et al: Treatment of choroid plexus tumors: a 20 -year single institutional experience. J Neurosurg Pediatr 10:398-405, 2012

12. Boivin MJ, Kakooza AM, Warf BC, Davidson LL, Grigorenko EL: Reducing neurodevelopmental disorders and disability through research and interventions. Nature 527:S155-S160, 2015

13. Brinker T, Stopa E, Morrison J, Klinge P: A new look at cerebrospinal fluid circulation. Fluids Barriers CNS 11:10, 2014

14. Britz GW, Kim DK, Loeser JD: Hydrocephalus secondary to diffuse villous hyperplasia of the choroid plexus. Case report and review of the literature. J Neurosurg 85:689691, 1996

15. Bush A: Primary ciliary dyskinesia. Acta Otorhinolaryngol Belg 54:317-324, 2000

16. Cardia E, Molina D, Abbate F, Mastroeni P, Stassi G, Germanà GP, et al: Morphological modifications of the choroid plexus in a rodent model of acute ventriculitis induced by gram-negative liquoral sepsis. Possible implications in the pathophysiology of hypersecretory hydrocephalus. Childs Nerv Syst 11:511-516, 1995

17. Carrion E, Hertzog JH, Medlock MD, Hauser GJ, Dalton HJ: Use of acetazolamide to decrease cerebrospinal fluid production in chronically ventilated patients with ventriculopleural shunts. Arch Dis Child 84:68-71, 2001

18. Casey KF, Vries JK: Cerebral fluid overproduction in the absence of tumor or villous hypertrophy of the choroid plexus. Childs Nerv Syst 5:332-334, 1989

19. Castañeyra-Ruiz L, González-Marrero I, González-Toledo JM, Castañeyra-Ruiz A, de Paz-Carmona H, CastañeyraPerdomo A, et al: Aquaporin-4 expression in the cerebrospinal fluid in congenital human hydrocephalus. Fluids Barriers CNS 10:18, 2013

20. Cataltepe O, Liptzin D, Jolley L, Smith TW: Diffuse villous hyperplasia of the choroid plexus and its surgical management. J Neurosurg Pediatr 5:518-522, 2010

21. Ceddia A, Di Rocco C, Carlucci A: [Hypersecretive congenital hydrocephalus due to choroid plexus villous hypertrophy associated with controlateral papilloma.] Minerva Pediatr 45:363-367, 1993 (Ital)

22. Chen J, Knowles HJ, Hebert JL, Hackett BP: Mutation of 
the mouse hepatocyte nuclear factor/forkhead homologue 4 gene results in an absence of cilia and random left-right asymmetry. J Clin Invest 102:1077-1082, 1998

23. Christensen HL, Nguyen AT, Pedersen FD, Damkier HH: $\mathrm{Na}^{+}$dependent acid-base transporters in the choroid plexus; insights from slc4 and slc9 gene deletion studies. Front Physiol 4:304, 2013

24. Christensen IB, Gyldenholm T, Damkier HH, Praetorius J: Polarization of membrane associated proteins in the choroid plexus epithelium from normal and slc4a10 knockout mice. Front Physiol 4:344, 2013

25. Cushing H: Studies on the cerebro-spinal fluid: I. Introduction. J Med Res 31:1-19, 1914

26. Cutler RW, Page L, Galicich J, Watters GV: Formation and absorption of cerebrospinal fluid in man. Brain 91:707720, 1968

27. D’Ambrosio AL, O'Toole JE, Connolly ES Jr, Feldstein NA: Villous hypertrophy versus choroid plexus papilloma: a case report demonstrating a diagnostic role for the proliferation index. Pediatr Neurosurg 39:91-96, 2003

28. Damkier HH, Brown PD, Praetorius J: Cerebrospinal fluid secretion by the choroid plexus. Physiol Rev 93:18471892,2013

29. Damkier HH, Brown PD, Praetorius J: Epithelial pathways in choroid plexus electrolyte transport. Physiology (Bethesda) 25:239-249, 2010

30. Dandy WE: Experimental hydrocephalus. Ann Surg 70:129-142, 1919

31. Dandy WE: Extirpation of the choroid plexus of the lateral ventricles in communicating hydrocephalus. Ann Surg 68:569-579, 1918

32. Davy BE, Robinson ML: Congenital hydrocephalus in hy3 mice is caused by a frameshift mutation in Hydin, a large novel gene. Hum Mol Genet 12:1163-1170, 2003

33. De Rougemont J, Ames A III, Nesbett FB, Hofmann HF: Fluid formed by choroid plexus; a technique for its collection and a comparison of its electrolyte composition with serum and cisternal fluids. J Neurophysiol 23:485-495, 1960

34. Del Bigio MR: The ependyma: a protective barrier between brain and cerebrospinal fluid. Glia 14:1-13, 1995

35. Di Rocco C, Iannelli A: Poor outcome of bilateral congenital choroid plexus papillomas with extreme hydrocephalus. Eur Neurol 37:33-37, 1997

36. Di Rocco C, Pettorossi VE, Caldarelli M, Mancinelli R, Velardi F: Communicating hydrocephalus induced by mechanically increased amplitude of the intraventricular cerebrospinal fluid pressure: experimental studies. Exp Neurol 59:40-52, 1978

37. Egnor M, Zheng L, Rosiello A, Gutman F, Davis R: A model of pulsations in communicating hydrocephalus. Pediatr Neurosurg 36:281-303, 2002

38. Eisenberg HM, McComb JG, Lorenzo AV: Cerebrospinal fluid overproduction and hydrocephalus associated with choroid plexus papilloma. J Neurosurg 40:381-385, 1974

39. Erman T, Göçer AI, Erdoğan S, Tuna M, Ildan F, Zorludemir S: Choroid plexus papilloma of bilateral lateral ventricle. Acta Neurochir (Wien) 145:139-143, 2003

40. Fairburn B: Choroid plexus papilloma and its relation to hydrocephalus. J Neurosurg 17:166-171, 1960

41. Faivre J: Structure du conarium et des plexus choroide chez l'hommes et des animaux. Gaz Med Paris 9:555-556, 1854

42. Feng X, Papadopoulos MC, Liu J, Li L, Zhang D, Zhang H, et al: Sporadic obstructive hydrocephalus in Aqp4 null mice. J Neurosci Res 87:1150-1155, 2009

43. Filippidis AS, Kalani MY, Rekate HL: Hydrocephalus and aquaporins: lessons learned from the bench. Childs Nerv Syst 27:27-33, 2011

44. Fisone G, Snyder GL, Fryckstedt J, Caplan MJ, Aperia
A, Greengard P: $\mathrm{Na}^{+}, \mathrm{K}^{+}$-ATPase in the choroid plexus. Regulation by serotonin/protein kinase C pathway. J Biol Chem 270:2427-2430, 1995

45. Fujimoto Y, Matsushita H, Plese JP, Marino R Jr: Hydrocephalus due to diffuse villous hyperplasia of the choroid plexus. Case report and review of the literature. Pediatr Neurosurg 40:32-36, 2004

46. Fujimura M, Onuma T, Kameyama M, Motohashi O, Kon $\mathrm{H}$, Yamamoto K, et al: Hydrocephalus due to cerebrospinal fluid overproduction by bilateral choroid plexus papillomas. Childs Nerv Syst 20:485-488, 2004

47. Gagnon KB, Delpire E: Molecular physiology of SPAK and OSR1: two Ste20-related protein kinases regulating ion transport. Physiol Rev 92:1577-1617, 2012

48. Gagnon KB, England R, Delpire E: Volume sensitivity of cation- $\mathrm{Cl}^{-}$cotransporters is modulated by the interaction of two kinases: Ste20-related proline-alanine-rich kinase and WNK4. Am J Physiol Cell Physiol 290:C134-C142, 2006

49. Garg LC, Mathur PP: Effect of ouabain on cerebrospinal fluid formation after carbonic anhydrase inhibition. Arch Int Pharmacodyn Ther 213:190-194, 1975

50. Greitz D: Paradigm shift in hydrocephalus research in legacy of Dandy's pioneering work: rationale for third ventriculostomy in communicating hydrocephalus. Childs Nerv Syst 23:487-489, 2007

51. Gudeman SK, Sullivan HG, Rosner MJ, Becker DP: Surgical removal of bilateral papillomas of the choroid plexus of the lateral ventricles with resolution of hydrocephalus. Case report. J Neurosurg 50:677-681, 1979

52. Gupta P, Sodhi KS, Mohindra S, Saxena AK, Das A, Khandelwal N: Choroid plexus papilloma of the third ventricle: a rare infantile brain tumor. J Pediatr Neurosci 8:247-249, 2013

53. Hack M, Cohen AR: Acetazolamide plus furosemide for periventricular dilatation: lessons for drug therapy in children. Lancet 352:418-419, 1998

54. Haliasos N, Brew S, Robertson F, Hayward R, Thompson D, Chakraborty A: Pre-operative embolisation of choroid plexus tumours in children. Part II. Observations on the effects on CSF production. Childs Nerv Syst 29:71-76, 2013

55. Hallaert GG, Vanhauwaert DJ, Logghe K, Van den Broecke C, Baert E, Van Roost D, et al: Endoscopic coagulation of choroid plexus hyperplasia. J Neurosurg Pediatr 9:169177,2012

56. Hirano H, Hirahara K, Asakura T, Shimozuru T, Kadota K, Kasamo S, et al: Hydrocephalus due to villous hypertrophy of the choroid plexus in the lateral ventricles. Case report. $\mathbf{J}$ Neurosurg 80:321-323, 1994

57. Holloway LS Jr, Cassin S: Effect of acetazolamide and ouabain on CSF production rate in the newborn dog. Am J Physiol 223:503-506, 1972

58. Husted RF, Reed DJ: Regulation of cerebrospinal fluid bicarbonate by the cat choroid plexus. J Physiol 267:411428,1977

59. Iencean SM: Simultaneous hypersecretion of CSF and of brain interstitial fluid causes idiopathic intracranial hypertension. Med Hypotheses 61:529-532, 2003

60. Iliff JJ, Chen MJ, Plog BA, Zeppenfeld DM, Soltero M, Yang L, et al: Impairment of glymphatic pathway function promotes tau pathology after traumatic brain injury. $\mathbf{J}$ Neurosci 34:16180-16193, 2014

61. Iliff JJ, Lee H, Yu M, Feng T, Logan J, Nedergaard M, et al: Brain-wide pathway for waste clearance captured by contrast-enhanced MRI. J Clin Invest 123:1299-1309, 2013

62. Iliff JJ, Wang M, Zeppenfeld DM, Venkataraman A, Plog BA, Liao Y, et al: Cerebral arterial pulsation drives paravascular CSF-interstitial fluid exchange in the murine brain. J Neurosci 33: 18190-18199, 2013 
63. International PHVD Drug Trial Group: International randomised controlled trial of acetazolamide and furosemide in posthaemorrhagic ventricular dilatation in infancy. Lancet 352:433-440, 1998

64. Iplikcioglu AC, Bek S, Gökduman CA, Bikmaz K, Cosar M: Diffuse villous hyperplasia of choroid plexus. Acta Neurochir (Wien) 148:691-694, 2006

65. Javaheri S, Wagner KR: Bumetanide decreases canine cerebrospinal fluid production. In vivo evidence for $\mathrm{NaCl}$ cotransport in the central nervous system. J Clin Invest 92:2257-2261, 1993

66. Jessen NA, Munk AS, Lundgaard I, Nedergaard M: The glymphatic system: a beginner's guide. Neurochem Res 40:2583-2599, 2015

67. Johanson C, McMillan P, Tavares R, Spangenberger A, Duncan J, Silverberg G, et al: Homeostatic capabilities of the choroid plexus epithelium in Alzheimer's disease. Cerebrospinal Fluid Res 1:3, 2004

68. Johanson CE, Murphy VA, Dyas M: Ethacrynic acid and furosemide alter $\mathrm{Cl}, \mathrm{K}$, and $\mathrm{Na}$ distribution between blood, choroid plexus, CSF, and brain. Neurochem Res 17:10791085,1992

69. Johansson P, Dziegielewska K, Saunders N: Low levels of $\mathrm{Na}, \mathrm{K}-\mathrm{ATP}$ ase and carbonic anhydrase II during choroid plexus development suggest limited involvement in early CSF secretion. Neurosci Lett 442:77-80, 2008

70. Johnson DC, Singer S, Hoop B, Kazemi H: Chloride flux from blood to CSF: inhibition by furosemide and bumetanide. J Appl Physiol (1985) 63:1591-1600, 1987

71. Kahle KT, Kulkarni AV, Limbrick DD Jr, Warf BC: Hydrocephalus in children. Lancet 387:788-799, 2016

72. Kahle KT, Ring AM, Lifton RP: Molecular physiology of the WNK kinases. Annu Rev Physiol 70:329-355, 2008

73. Kahle KT, Simard JM, Staley KJ, Nahed BV, Jones PS, Sun D: Molecular mechanisms of ischemic cerebral edema: role of electroneutral ion transport. Physiology (Bethesda) 24:257-265, 2009

74. Karimy JK, Kahle KT, Kurland DB, Yu E, Gerzanich V, Simard JM: A novel method to study cerebrospinal fluid dynamics in rats. J Neurosci Methods 241:78-84, 2015

75. Keep RF, Xiang J, Betz AL: Potassium cotransport at the rat choroid plexus. Am J Physiol 267:C1616-C1622, 1994

76. Kennedy CR, Ayers S, Campbell MJ, Elbourne D, Hope P, Johnson A: Randomized, controlled trial of acetazolamide and furosemide in posthemorrhagic ventricular dilation in infancy: follow-up at 1 year. Pediatrics 108:597-607, 2001

77. Khanna A, Walcott BP, Kahle KT, Simard JM: Effect of glibenclamide on the prevention of secondary brain injury following ischemic stroke in humans. Neurosurg Focus 36(1):E11, 2014

78. Kousi M, Katsanis N: The genetic basis of hydrocephalus. Annu Rev Neurosci 39:409-435, 2016

79. Krishnamurthy S, Li J, Schultz L, McAllister JP II: Intraventricular infusion of hyperosmolar dextran induces hydrocephalus: a novel animal model of hydrocephalus. Cerebrospinal Fluid Res 6:16, 2009

80. Kulkarni AV, Riva-Cambrin J, Browd SR, Drake JM, Holubkov R, Kestle JR, et al: Endoscopic third ventriculostomy and choroid plexus cauterization in infants with hydrocephalus: a retrospective Hydrocephalus Clinical Research Network study. J Neurosurg Pediatr 14:224-229, 2014

81. Lapras C, Mertens P, Guilburd JN, Lapras C Jr, Pialat J, Patet JD: Choroid plexectomy for the treatment of chronic infected hydrocephalus. Childs Nerv Syst 4:139-143, 1988

82. Lehtinen MK, Bjornsson CS, Dymecki SM, Gilbertson RJ, Holtzman DM, Monuki ES: The choroid plexus and cerebrospinal fluid: emerging roles in development, disease, and therapy. J Neurosci 33:17553-17559, 2013
83. Libenson MH, Kaye EM, Rosman NP, Gilmore HE: Acetazolamide and furosemide for posthemorrhagic hydrocephalus of the newborn. Pediatr Neurol 20:185-191, 1999

84. Lindeman GJ, Dagnino L, Gaubatz S, Xu Y, Bronson RT, Warren HB, et al: A specific, nonproliferative role for E2F-5 in choroid plexus function revealed by gene targeting. Genes Dev 12:1092-1098, 1998

85. Lorenzo AV, Hornig G, Zavala LM, Boss V, Welch K: Furosemide lowers intracranial pressure by inhibiting CSF production. Z Kinderchir 41 (Suppl 1): 10-12, 1986

86. Mao X, Enno TL, Del Bigio MR: Aquaporin 4 changes in rat brain with severe hydrocephalus. Eur J Neurosci 23:2929-2936, 2006

87. McAllister JP II, Williams MA, Walker ML, Kestle JR, Relkin NR, Anderson AM, et al: An update on research priorities in hydrocephalus: overview of the third National Institutes of Health-sponsored symposium "Opportunities for Hydrocephalus Research: Pathways to Better Outcomes". J Neurosurg 123:1427-1438, 2015

88. McCarthy KD, Reed DJ: The effect of acetazolamide and furosemide on cerebrospinal fluid production and choroid plexus carbonic anhydrase activity. J Pharmacol Exp Ther 189: 194-201, 1974

89. Milhorat TH: Choroid plexus and cerebrospinal fluid production. Science 166: 1514-1516, 1969

90. Milhorat TH, Hammock MK, Davis DA, Fenstermacher JD: Choroid plexus papilloma. I. Proof of cerebrospinal fluid overproduction. Childs Brain 2:273-289, 1976

91. Milhorat TH, Hammock MK, Fenstermacher JD, Levin VA: Cerebrospinal fluid production by the choroid plexus and brain. Science 173:330-332, 1971

92. Morota N, Fujiyama Y: Endoscopic coagulation of choroid plexus as treatment for hydrocephalus: indication and surgical technique. Childs Nerv Syst 20:816-820, 2004

93. Murphy VA, Johanson CE: Acidosis, acetazolamide, and amiloride: effects on ${ }^{22} \mathrm{Na}$ transfer across the blood-brain and blood-CSF barriers. J Neurochem 52:1058-1063, 1989

94. Murphy VA, Smith QR, Rapoport SI: Homeostasis of brain and cerebrospinal fluid calcium concentrations during chronic hypo- and hypercalcemia. J Neurochem 47:17351741,1986

95. Nielsen S, Smith BL, Christensen EI, Agre P: Distribution of the aquaporin CHIP in secretory and resorptive epithelia and capillary endothelia. Proc Natl Acad Sci U S A 90:7275-7279, 1993

96. Nimjee SM, Powers CJ, McLendon RE, Grant GA, Fuchs HE: Single-stage bilateral choroid plexectomy for choroid plexus papilloma in a patient presenting with high cerebrospinal fluid output. J Neurosurg Pediatr 5:342-345, 2010

97. Nógrádi A, Kelly C, Carter ND: Localization of acetazolamide-resistant carbonic anhydrase III in human and rat choroid plexus by immunocytochemistry and in situ hybridisation. Neurosci Lett 151:162-165, 1993

98. Oi S, Di Rocco C: Proposal of "evolution theory in cerebrospinal fluid dynamics" and minor pathway hydrocephalus in developing immature brain. Childs Nerv Syst 22:662-669, 2006

99. Oshio K, Watanabe H, Song Y, Verkman AS, Manley GT: Reduced cerebrospinal fluid production and intracranial pressure in mice lacking choroid plexus water channel Aquaporin-1. FASEB J 19:76-78, 2005

100. Papadopoulos MC, Verkman AS: Potential utility of aquaporin modulators for therapy of brain disorders. Prog Brain Res 170:589-601, 2008

101. Park HW, Nam JH, Kim JY, Namkung W, Yoon JS, Lee JS, et al: Dynamic regulation of CFTR bicarbonate permeability by $\left[\mathrm{Cl}^{-}\right]_{\mathrm{i}}$ and its role in pancreatic bicarbonate secretion. Gastroenterology 139:620-631, 2010

102. Pawar SJ, Sharma RR, Mahapatra AK, Lad SD, Musa MM: 
Choroid plexus papilloma of the posterior third ventricle during infancy \& childhood: report of two cases with management morbidities. Neurol India 51:379-382, 2003

103. Peyre M, Bah A, Kalamarides M: Multifocal choroid plexus papillomas: case report. Acta Neurochir (Wien) 154:295299, 2012

104. Philips MF, Shanno G, Duhaime AC: Treatment of villous hypertrophy of the choroid plexus by endoscopic contact coagulation. Pediatr Neurosurg 28:252-256, 1998

105. Piechotta K, Lu J, Delpire E: Cation chloride cotransporters interact with the stress-related kinases Ste20-related prolinealanine-rich kinase (SPAK) and oxidative stress response 1 (OSR1). J Biol Chem 277:50812-50819, 2002

106. Pindrik J, Rocque BG, Arynchyna AA, Johnston JM, Rozzelle CJ: Radiographic markers of clinical outcomes after endoscopic third ventriculostomy with choroid plexus cauterization: cerebrospinal fluid turbulence and choroid plexus visualization. J Neurosurg Pediatr 18:287-295, 2016

107. Plotkin MD, Kaplan MR, Peterson LN, Gullans SR, Hebert $\mathrm{SC}$, Delpire E: Expression of the $\mathrm{Na}^{+}-\mathrm{K}^{+}-2 \mathrm{Cl}^{-}$cotransporter BSC2 in the nervous system. Am J Physiol 272:C173C183, 1997

108. Poca MA, Sahuquillo J: Short-term medical management of hydrocephalus. Expert Opin Pharmacother 6:1525-1538, 2005

109. Pople IK, Ettles D: The role of endoscopic choroid plexus coagulation in the management of hydrocephalus. Neurosurgery 36:698-702, 1995

110. Praetorius J: Water and solute secretion by the choroid plexus. Pflugers Arch 454:1-18, 2007

111. Radic JA, Vincer M, McNeely PD: Outcomes of intraventricular hemorrhage and posthemorrhagic hydrocephalus in a population-based cohort of very preterm infants born to residents of Nova Scotia from 1993 to 2010. J Neurosurg Pediatr 15:580-588, 2015

112. Raupp P: Acetazolamide in posthaemorrhagic ventricular dilatation. Lancet 352:1548-1549, 1998

113. Ray BS, Peck FC Jr: Papilloma of the choroid plexus of the lateral ventricles causing hydrocephalus in an infant. J Neurosurg 13:317-322, 1956

114. Redzic ZB, Segal MB: The structure of the choroid plexus and the physiology of the choroid plexus epithelium. Adv Drug Deliv Rev 56:1695-1716, 2004

115. Reed DJ: The effect of furosemide on cerebrospinal fluid flow in rabbits. Arch Int Pharmacodyn Ther 178:324330, 1969

116. Russell JM: Sodium-potassium-chloride cotransport. Physiol Rev 80:211-276, 2000

117. Saito A, Nishimura S, Fujita T, Sasaki T, Nishijima M: A case of difficult management of fluid-electrolyte imbalance in choroid plexus papilloma. Neurol Med Chir (Tokyo) 54:659-663, 2014

118. Sapiro R, Kostetskii I, Olds-Clarke P, Gerton GL, Radice GL, Strauss JF III: Male infertility, impaired sperm motility, and hydrocephalus in mice deficient in sperm-associated antigen 6. Mol Cell Biol 22:6298-6305, 2002

119. Scarff JE: The treatment of nonobstructive (communicating) hydrocephalus by endoscopic cauterization of the choroid plexuses. J Neurosurg 33:1-18, 1970

120. Schoeman J, Donald P, van Zyl L, Keet M, Wait J: Tuberculous hydrocephalus: comparison of different treatments with regard to ICP, ventricular size and clinical outcome. Dev Med Child Neurol 33:396-405, 1991

121. Segal MB: Extracellular and cerebrospinal fluids. J Inherit Metab Dis 16:617-638, 1993

122. Smith DE, Johanson CE, Keep RF: Peptide and peptide analog transport systems at the blood-CSF barrier. Adv Drug Deliv Rev 56:1765-1791, 2004
123. Smith ZA, Moftakhar P, Malkasian D, Xiong Z, Vinters HV, Lazareff JA: Choroid plexus hyperplasia: surgical treatment and immunohistochemical results. Case report. J Neurosurg 107 (3 Suppl):255-262, 2007

124. Spector R, Keep RF, Robert Snodgrass S, Smith QR, Johanson CE: A balanced view of choroid plexus structure and function: Focus on adult humans. Exp Neurol 267:7886,2015

125. Stone SS, Warf BC: Combined endoscopic third ventriculostomy and choroid plexus cauterization as primary treatment for infant hydrocephalus: a prospective North American series. J Neurosurg Pediatr 14:439-446, 2014

126. Strahle J, Garton HJ, Maher CO, Muraszko KM, Keep RF, Xi G: Mechanisms of hydrocephalus after neonatal and adult intraventricular hemorrhage. Transl Stroke Res 3 (Suppl 1):25-38, 2012

127. Tamburrini G, Caldarelli M, Di Rocco F, Massimi L, D'Angelo L, Fasano T, et al: The role of endoscopic choroid plexus coagulation in the surgical management of bilateral choroid plexuses hyperplasia. Childs Nerv Syst 22:605608, 2006

128. Tully HM, Ishak GE, Rue TC, Dempsey JC, Browd SR, Millen KJ, et al: Two hundred thirty-six children with developmental hydrocephalus: causes and clinical consequences. J Child Neurol 31:309-320, 2016

129. Verkman AS: Mammalian aquaporins: diverse physiological roles and potential clinical significance. Expert Rev Mol Med 10:e13, 2008

130. Vogh BP, Godman DR, Maren TH: Effect of $\mathrm{AlCl}_{3}$ and other acids on cerebrospinal fluid production: a correction. $\mathbf{J}$ Pharmacol Exp Ther 243:35-39, 1987

131. Wagshul ME, Eide PK, Madsen JR: The pulsating brain: A review of experimental and clinical studies of intracranial pulsatility. Fluids Barriers CNS 8:5, 2011

132. Wagshul ME, McAllister JP, Rashid S, Li J, Egnor MR, Walker ML, et al: Ventricular dilation and elevated aqueductal pulsations in a new experimental model of communicating hydrocephalus. Exp Neurol 218:33-40, 2009

133. Warf B, Ondoma S, Kulkarni A, Donnelly R, Ampeire M, Akona J, et al: Neurocognitive outcome and ventricular volume in children with myelomeningocele treated for hydrocephalus in Uganda. J Neurosurg Pediatr 4:564-570, 2009

134. Warf BC: Comparison of endoscopic third ventriculostomy alone and combined with choroid plexus cauterization in infants younger than 1 year of age: a prospective study in 550 African children. J Neurosurg 103 (6 Suppl):475-481, 2005

135. Warf BC: Congenital idiopathic hydrocephalus of infancy: the results of treatment by endoscopic third ventriculostomy with or without choroid plexus cauterization and suggestions for how it works. Childs Nerv Syst 29:935-940, 2013

136. Warf BC: Hydrocephalus associated with neural tube defects: characteristics, management, and outcome in subSaharan Africa. Childs Nerv Syst 27:1589-1594, 2011

137. Warf BC: The impact of combined endoscopic third ventriculostomy and choroid plexus cauterization on the management of pediatric hydrocephalus in developing countries. World Neurosurg 79 (2 Suppl):S23.e13-S23.e15, 2013

138. Warf BC: Three steps forward and 2 steps back: the Echternach procession toward optimal hydrocephalus treatment. Neurosurgery 61 (Suppl 1):105-110, 2014

139. Warf BC, Dewan M, Mugamba J: Management of DandyWalker complex-associated infant hydrocephalus by combined endoscopic third ventriculostomy and choroid plexus cauterization. J Neurosurg Pediatr 8:377-383, 2011

140. Warf BC, Mugamba J, Kulkarni AV: Endoscopic third ventriculostomy in the treatment of childhood hydrocephalus in Uganda: report of a scoring system that predicts success. J Neurosurg Pediatr 5:143-148, 2010 
141. Warf BC, Tracy S, Mugamba J: Long-term outcome for endoscopic third ventriculostomy alone or in combination with choroid plexus cauterization for congenital aqueductal stenosis in African infants. J Neurosurg Pediatr 10:108111,2012

142. Warren DT, Hendson G, Cochrane DD: Bilateral choroid plexus hyperplasia: a case report and management strategies. Childs Nerv Syst 25:1617-1622, 2009

143. Welch K, Strand R, Bresnan M, Cavazzuti V: Congenital hydrocephalus due to villous hypertrophy of the telencephalic choroid plexuses. Case report. J Neurosurg 59:172175,1983

144. Wellons JC III, Tubbs RS, Leveque JC, Blount JP, Oakes WJ: Choroid plexectomy reduces neurosurgical intervention in patients with hydranencephaly. Pediatr Neurosurg 36: $148-152,2002$

145. Whitelaw A, Kennedy CR, Brion LP: Diuretic therapy for newborn infants with posthemorrhagic ventricular dilatation. Cochrane Database Syst Rev (2):CD002270, 2001

146. Wolburg H, Paulus W: Choroid plexus: biology and pathology. Acta Neuropathol 119:75-88, 2010

147. Wu Q, Delpire E, Hebert SC, Strange K: Functional demonstration of $\mathrm{Na}^{+}-\mathrm{K}^{+}-2 \mathrm{Cl}^{-}$cotransporter activity in isolated, polarized choroid plexus cells. Am J Physiol 275:C1565C1572, 1998

148. Yan Y, Dalmasso G, Nguyen HT, Obertone TS, Sitaraman SV, Merlin D: Ste20-related proline/alanine-rich kinase (SPAK) regulated transcriptionally by hyperosmolarity is involved in intestinal barrier function. PLoS One 4:e5049, 2009
149. Yoshino A, Katayama Y, Watanabe T, Kurihara J, Kimura S: Multiple choroid plexus papillomas of the lateral ventricle distinct from villous hypertrophy. Case report. J Neurosurg 88:581-585, 1998

\section{Disclosures}

The authors report no conflict of interest concerning the materials or methods used in this study or the findings specified in this paper.

\section{Author Contributions}

Conception and design: Kahle, Karimy, Duran, DiLuna, Gerzanich, Simard. Acquisition of data: Kahle, Karimy, Duran, Hu, Gavankar, Gaillard, Rice. Analysis and interpretation of data: Karimy, Duran, Hu, Gavankar, Gaillard, Gerzanich, Simard, Rice. Drafting the article: Kahle, Karimy, Duran, Hu, Gavankar, Gaillard. Critically revising the article: Kahle, Karimy, Duran, $\mathrm{Hu}$, Gerzanich, Simard. Reviewed submitted version of manuscript: Kahle, Karimy, Duran, Bayri, DiLuna, Gerzanich, Simard. Approved the final version of the manuscript on behalf of all authors: Kahle. Administrative/technical/material support: Kahle, DiLuna. Study supervision: Kahle.

\section{Correspondence}

Kristopher T. Kahle, Department of Neurosurgery, Yale School of Medicine, 300 Cedar St., TAC S311, New Haven, CT 06519. email: kristopher.kahle@yale.edu. 